\title{
Modelling the Socio-Ecological System Dynamics of Rubber Agroforests to Design Reward Mechanisms for Agro-biodiversity Conservation
}

\author{
Grace B. Villamor ${ }^{\text {ab }}$, Utkir Djanibekov ${ }^{a}$, Quang Bao Le ${ }^{\text {c }}$, and Paul L.G. Vlek ${ }^{a}$ \\ ${ }^{a}$ Center for Development Research (ZEF), University of Bonn, Germany; ${ }^{b}$ World Agroforestry Center \\ (ICRAF), Bogor, Indonesia; ${ }^{c}$ Natural and Social Science Interface (NSSI), Swiss Federal Institute of \\ Technology Zurich, Universitaetstrasse 22, 8092 Zurich, Switzerland. \\ (Email: gracev@uni-bonn.de)
}

\begin{abstract}
An agent-based modelling approach (LB-LUDAS model) was applied to simulate and visualize the temporal and spatial scale effects of the Payments for Ecosystem Services (PES) scheme on the trade-offs between goods and services in the rubber agroforest landscapes in Jambi Province, (Sumatra) Indonesia. The PES scheme under investigation is a form of eco-certification of biodiversity-friendly rubber agroforests, as an economic incentive to keep rubber agroforests from conversion into monoculture plantations. Within the model, we integrated the concept of PES conditionality, where biodiversity performance measures were set for household agents to qualify for incentives. On the other hand, species richness, carbon sequestration, and natural succession sub-models are imbedded in the landscape agents. During the simulation, we looked at three different price scenarios to determine how they will affect the land-use decision of the agents and the ecosystem services supply. The main results showed that PES for rubber agroforests could offer synergies among carbon emission reduction, biodiversity and livelihoods when compared to the existing land-use practices. At the same time, the scheme could reduce the trade-offs resulting from possible land-use/cover change. The results of the simulation were validated using a role-playing game testing responses to external agents.
\end{abstract}

Keywords: Agent-based model, biodiversity performance indicator, conditionality, eco-certification, ecosystem service trade-offs, land-use/cover change, price effect 


\section{INTRODUCTION}

Several studies have illustrated the effect of payment for ecosystem services (PES) on land use decision making, and the impact of social norms on the enrollment of PES, and assessed the effect on household income using agent-based models (ABM) (Chen et al., 2012; Evans et al., 2011; Sun and Müller, 2013). However, understanding how PES schemes and households adoption affects the goods and ecosystem services (ES) delivery are very few. In this paper, we explore the role of PES schemes to reduce the ES tradeoffs or enhance the synergies of various ES using ABM (i.e., Lubuk-Beringin - Land Use Dynamic Simulator or LB-LUDAS model). Since very few primary forests are left in Indonesia, maintaining agroforests is one of the last options for supporting the remaining biodiversity, and incentives to prevent further conversion to less biologically diverse land uses are seen as an urgent need. The type of PES scheme under investigation is an eco-certification or eco-labeling of rubber agroforests, in which a price-premium is added if a household will adopt and meet all the biodiversity performance criteria. The research question is whether eco-labelling or eco-certification of latex from rubber agroforest under a PES scheme could be a promising option for at least part of the households as well as by how much price increase is appropriate to make sure the continuous ES supply. Thus, we explored the effect of different price scenario under the PES scheme on the land-use decisions of the households.

\section{METHODS}

\subsection{Study area and data}

The study site includes three villages, namely Lubuk Beringin, Laman Panjang, and Buat, all located in Jambi Province, (Sumatra) Indonesia. Together, they have a total population of 2,207 inhabitants belonging to 553 households (Rantau Pandan Statistics 2003). The main source of staple food is rice paddies; the main source of income is rubber (Hevea brasiliensis) and occasionally durian and other local fruits obtained from the rubber agroforests. Rubber agroforest used to be the dominant land use in Jambi Province (van Noordwijk et al., 2012). However, due to the low latex productivity, farmers are now attracted to convert their farm lands into more profitable land use such as oil palm and monoculture rubber plantations.

We surveyed 95 randomly selected households in the study area from a total population of 550 households. The survey was conducted between February and March 2010 with the objective to elicit data on household characteristics, preferences, and behaviors. It explored: (1) household profiles and farm characteristics (from which existing land-use choices were generated); and (2) households' willingness to adopt PES. Based on the survey results we characterized the households using principal component and cluster analyses and identified two categories (Villamor, 2012). Type 1 households were described as "better-off households," and Type 2 households as "poor households." For each household type the existing household land-use choices were assessed using a multinomial logistic regression analysis. Willingness to adopt PES was assessed using a binary logistic regression analysis (Villamor, 2012; Villamor et al., 2011). The results of the land-use choice and willingness to adopt PES analyses became the basis of agent decision making for the business-as-usual (BAU) model scenario, along with PES scenarios.

\subsection{LB-LUDAS: model description}

The study applies the LUDAS framework (Le et al., 2008). The description of the LUDAS model using the ODD protocol (Overview, Design concept, and Details) (Grimm et al., 2010) is described in Le et al. (2010). For application of PES, in the following the modified and new features in the LB-LUDAS model are described (Villamor, 2012; Villamor et al., under review).

\section{Overview}

Agents, state variables and scales: There are two types of agents. First, human agents are representations of individual farming households with state variables on social, natural, physical, financial and human resources, and policy access. Second, landscape agents (i.e., congruent land pixels or patches) with state variables corresponding to GIS-raster layers of biophysical spatial variables, spatial neighbourhood characteristics, spatial economic variables (e.g., proximate distance to road and town centre or market), spatial institutional variables (e.g. owner and protection zoning), and households' landscape vision (Le et al. 2008). One grid cell or pixel represents $30 \mathrm{~m}$ x $30 \mathrm{~m}$, and the model landscape covers $156 \mathrm{~km}^{2}$. The adaptive traits of each individual agent are explicitly processed mainly by land-use decisions and the change in 
behaviour strategies (i.e., preference coefficient of land-use choice function and willingness to adopt PES policies, and structure of labour allocation).

Process overview and scheduling: One time step represents one year. The main time loop of the simulation program, called annual production cycle, includes sequential steps, which are agent-based and integrated with patch-based processes. The ten basic simulation steps are: (1) set-up initial state of the system, (2) update agent and patch attributes, (3) adopt behaviour parameters, (4) farmland choice, (5) forest choice, (6) other income sources, (7) update changes in agent and patch attributes, (8) create new agents, (9) translate annual land-use changes, and (10) calculate ecosystem services (e.g. crop productivity, species richness, and carbon sequestration).

Details

Input: Data and parameters were parameterized and calibrated for each sub-model (Table 1).

Table 1 External input data and sub-models in LB-LUDAS model

\begin{tabular}{|c|c|c|}
\hline Sub-model & Parameter & Data source \\
\hline $\begin{array}{l}\text { Carbon stocks per land-cover } \\
\text { type }\end{array}$ & Time average C-density: $1-150 \mathrm{Mg} \mathrm{ha}^{-1} \mathrm{yr}$ & Tomich et al. 1998 \\
\hline $\begin{array}{l}\text { Forest/ rubber agroforest growth } \\
(\mathrm{Le}, 2005)\end{array}$ & Basal area: $21-41 \mathrm{~m}^{2} \mathrm{ha}^{-1}$ & $\begin{array}{l}\text { Rahayu 2009; Rasnovi } \\
2006\end{array}$ \\
\hline Land-use choice & $\begin{array}{l}\text { Characteristics of farm plot owner (e.g. age, education status, } \\
\text { income, etc.); natural land attributes (e.g. wetness index, slope, } \\
\text { etc.); neighborhood characteristics of land use (e.g. enrichment } \\
\text { factor of land-use types) }\end{array}$ & $\begin{array}{l}\text { Field survey } \\
\text { GIS-based calculations }\end{array}$ \\
\hline PES adoption & $\begin{array}{l}\text { Characteristics of farm plot owner (e.g. age, education status, } \\
\text { income, etc.); access to conservation policies }\end{array}$ & Field survey \\
\hline Rubber agroforest latex yield & $800-1200 \mathrm{~kg} \mathrm{ha}^{-1} \mathrm{yr}^{-1}$ & Field survey \\
\hline Rubber monoculture yield & $1200-1800 \mathrm{~kg} \mathrm{ha}^{-1} \mathrm{yr}^{-1}(2009-2010)$ & ICRAF data \\
\hline Species richness & 26-80 tree species per ha & Rahayu 2009 \\
\hline Upland rice yield & $600-800 \mathrm{~kg} \mathrm{ha}^{-1} \mathrm{yr}^{-1}$ & Field survey \\
\hline
\end{tabular}

Sub-models

PES-adoption sub-model (nested within Land-use choice sub-model) calculates stochastically the probability of the household agents whether to adopt or not to adopt the PES scheme based on their preference coefficients. These preference coefficients were derived from binary logistic regression (Villamor et al., 2011). The sub-model is linked to the Calculate-species-richness sub-model, creating the interaction between socio-economic state variables and the bio-physical processes in the systems. This sub-model is integrated in the agent's decision-making routines with a simple rule base: (1) if the household decides to adopt the PES scheme, then do rubber agroforest, (2) otherwise look for other land-use types for current landholdings. If the latter case is realized, the household agent will execute Land-use choice sub-model. The main variables of the sub-models are shown in Table 2.

Calculate-species-richness sub-model deterministically calculates the estimated species richness of the land cover (e.g. rubber agroforests). The estimated species richness of rubber-agroforest serves as a biodiversity performance measurement for the eco-certification scheme (see section 2.3). The species richness is estimated using the power function of species-area relationship (Villamor et al., under review).

Natural-transition sub-model performs the natural succession among vegetation types based on accumulated vegetation growth and ecological edge effects. Its rules are based on the evaluation of four patch variables, namely (i) previous cover type, (ii) life span of existing cover type, (iii) existing stand basal area, and (iv) distance to nearest forest.

Carbon emission sub-model: The land-cover-derived C-stocks method is applied by assigning the timeaveraged C-stocks and is estimated in the LB-LUDAS model.

Financial-return sub-model estimates the annual financial returns to household agents from major land uses. The yields generated from the crop production sub-model (rubber and rice) are captured by this sub-model, 
where all crop production costs (e.g., labour and agro-chemical input costs) are deducted from annual revenues. At the end of each time step the results are used to estimate the net present value (NPV) of the different land uses, which serves as an indicator of the livelihood options of household agents in each scenario. To investigate the financial returns of land-use types (i.e., rubber plantation, rubber agroforest, and rice), we calculated their NPV over 20 years. The interest rate is $20 \%$. Rice value is US\$ $1 \mathrm{~kg}^{-1}$ and dry rubber is US\$ $2.5 \mathrm{~kg}^{-1}$. Variable costs of each crop were derived from Wulan et al. (2008) and labour costs are US\$ 2 day $^{-1}$. We assumed that an additional income of up to US\$ $70 \mathrm{ha}^{-1} \mathrm{yr}^{-1}$ is generated beginning at year eight from fruit trees intercropped within rubber agroforests as observed from the field survey.

\subsection{Scenario}

The scenarios are primarily based on household land-use decisions under different policy contexts.

1) Business-as-usual (BAU) scenario - agents operate on the premise that there is no policy intervention available. We simulated existing land-uses on the agent's landholdings over a 20-year period with changes to biophysical conditions based on temporal dynamics and population increase.

2) PES scenario - agents operate on the premise that a conditional eco-certification scheme is offered. First, the agent assesses the existing land-use choice. Then, the agent assesses whether to adopt PES or not using the PES-adoption sub-model. If an agent adopts PES their biodiversity performance measures (Table 2) are generated by two sub-models (i.e., Calculatespecies-richness and Forest-Growth-Response, Le et al. (2008)) and evaluated for PES compliance

A price premium is awarded to agents that meet all of these criteria and no payments are available for partial compliance. To understand the possible amount of price premium, we tested a $10 \%, 20 \%$ and $40 \%$ increase of price value from the baseline price of (US\$ $2.5^{1}$ )

\subsection{Run set up summary}

A total of five simulation runs were independently performed for BAU scenario while three simulation runs were performed for each price scenario under PES. For each scenario, we took the average values. Each run has 20 time steps or years and the model is programmed in Netlogo version 4.1.

\subsection{Validation}

A social validation approach was conducted to validate the results of the LB-LUDAS simulation through role-playing games (Villamor and van Noordwijk, 2011). Land-use game boards were used to represent each of the target villages and same survey respondents played the games where they could directly change their land-use/cover type according to their negotiations with actors promoting either conversion or conservation of rubber agroforests.

\section{RESULTS AND DISCUSSION}

\subsection{Land-use/cover change}

The land-use change trends of three main land uses simulated under BAU and PES scenario (Figure 1). A decreasing trend of rice field is observed both under the BAU and PES scenarios. For agroforests, a larger rubber agroforest area was simulated under the PES scenario than BAU, suggesting that rubber agroforest is preferable by household agents under the PES scenario. No change of rubber monoculture was observed under PES scenario while a decreasing trend of rubber monoculture was observed under the BAU scenario.

Within the PES scenario, we compared the simulated land use map according to different price increase on baseline price with the 2005 land-use map to see the potential change. Table 3 summarizes the land-use

\footnotetext{
${ }^{1}$ Average price per kilogram of dry rubber was US\$ 2.5 during the data collection (2010).
} 
changes at $10 \%, 20 \%$ and $40 \%$ increase of baseline price. Results show as the price premium increases, the area of rice field increases while the area of rubber monoculture decreases. For rubber agroforests, no apparent trend was observed that links to the price scenario.

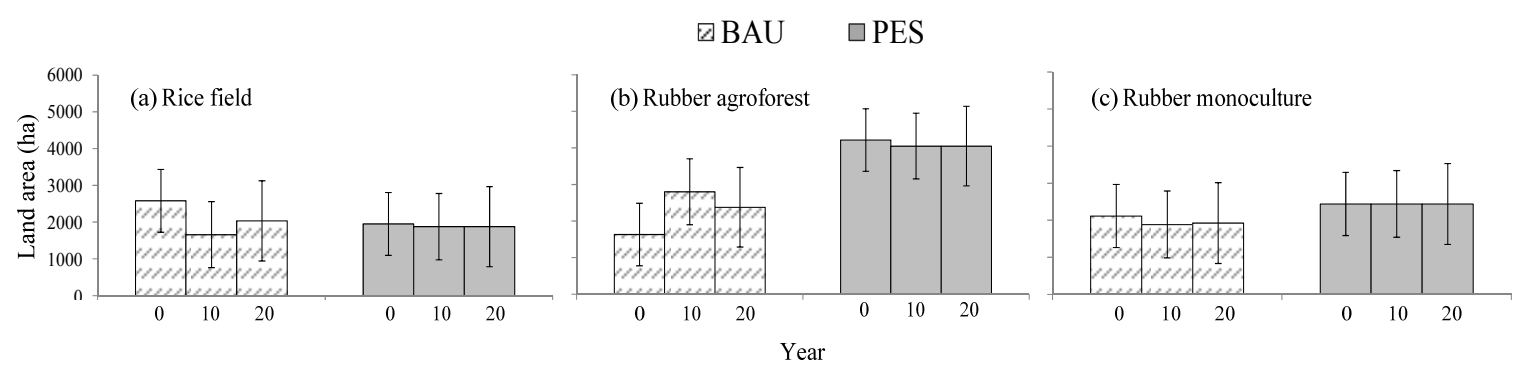

Figure 1. Simulated land-use trends under the BAU and PES scenarios.

Table 3 Land-use change compared to 2005 land-use map.

\begin{tabular}{lcccc}
\hline Land use & $\begin{array}{c}\text { \% land area in } \\
2005 \text { land use } \\
\text { map }\end{array}$ & $\begin{array}{c}10 \% \text { increase of } \\
\text { baseline price }\end{array}$ & $\begin{array}{c}\text { \% land area after year 20 } \\
\text { baseline price }\end{array}$ & $\begin{array}{c}40 \% \text { increase of } \\
\text { baseline price }\end{array}$ \\
\cline { 3 - 5 } Rice field & $1 ., 5$ & 11.2 & 12.3 & 15.6 \\
Rubber agroforest & 14.4 & 14.0 & 15.3 & 12.4 \\
Rubber monoculture & 23.0 & 14.9 & 13.1 & 12.8 \\
\hline
\end{tabular}

\subsection{Ecosystem services (ES) delivery indicators}

From those land-use changes, the potential impact on the ES delivery was estimated. Between BAU and PES scenarios, the key indicators for ES delivery are presented in Table 4. The results suggest that under the PES scenario performs better for maintaining species richness, and reducing carbon emissions. In terms of price scenarios, biodiversity and carbon emissions did not differ substantially.

With regard to yields, the rubber yield from agroforest increases as the price premium increases, along with its uncertainty (i.e., standard deviation). However, the rice yield is highest under the BAU scenario while a gradual decreasing trend of yield as the price increases in price premium under the PES scenario. The yield of rubber monoculture would be highest with $20 \%$ PES price premium though would not differ substantially in comparison to other scenarios.

In terms of PES adoption, the highest number of PES adopters is at the $40 \%$ price premium. This suggests that an increase of price premium would increase the number of PES adopters.

Table 4 Simulated results in three scenarios based on key indicators

\begin{tabular}{|c|c|c|c|c|}
\hline \multirow[t]{2}{*}{ Indicator } & \multicolumn{4}{|c|}{ Scenario } \\
\hline & BAU & $\begin{array}{r}\text { PES }(10 \% \\
\text { price premium) }\end{array}$ & $\begin{array}{r}\text { PES (20\% } \\
\text { price premium) }\end{array}$ & $\begin{array}{r}\text { PES }(40 \% \text { price } \\
\text { premium })\end{array}$ \\
\hline \multicolumn{5}{|l|}{ Biodiversity } \\
\hline a. Species richness & $64 \%$ & $92 \%$ & $93 \%$ & $91 \%$ \\
\hline b. Species loss & $36 \%$ & $8 \%$ & $7 \%$ & $9 \%$ \\
\hline Carbon emissions $\left(\mathrm{Mg} \mathrm{ha}^{-1} \mathrm{yr}^{-1}\right)$ & 0.4 & 0.2 & 0.2 & 0.2 \\
\hline b. Rubber agroforest $\left(\mathrm{kg} \mathrm{ha}^{-1} \mathrm{yr}^{-1}\right)$ & $1,026 \pm 222$ & $1,032 \pm 381$ & $1,230 \pm 419$ & $1,227 \pm 441$ \\
\hline c. Rubber monoculture $\left(\mathrm{kg} \mathrm{ha}^{-1} \mathrm{yr}^{-1}\right)$ & $1,036 \pm 82$ & $1,033 \pm 90$ & $1,051 \pm 127$ & $1,027 \pm 94$ \\
\hline PES-Adopters & 0 & $32 \%$ & $36 \%$ & $40 \%$ \\
\hline
\end{tabular}




\subsection{Potential income from key land uses}

Different PES values would lead to different NPV of land uses (Figure 2). Results show that over 20 year period, rubber monoculture has the highest net returns (US\$ 1,360) even at 10\% price increase for PES for rubber agroforest (Figure 2a). Consequent increase in PES values for rubber agroforest would lead that this land use would have the highest net returns (e.g., at 20\% price increase the NPV is US\$ 1,940, and at $40 \%$ price increase the NPV is US\$ 2,960). At the same time, returns from rubber agroforest and monoculture would substantially vary over the years due to their yield fluctuations. In contrasts, the returns from rice would be lowest, yet variability in its NPV would be also lowest.

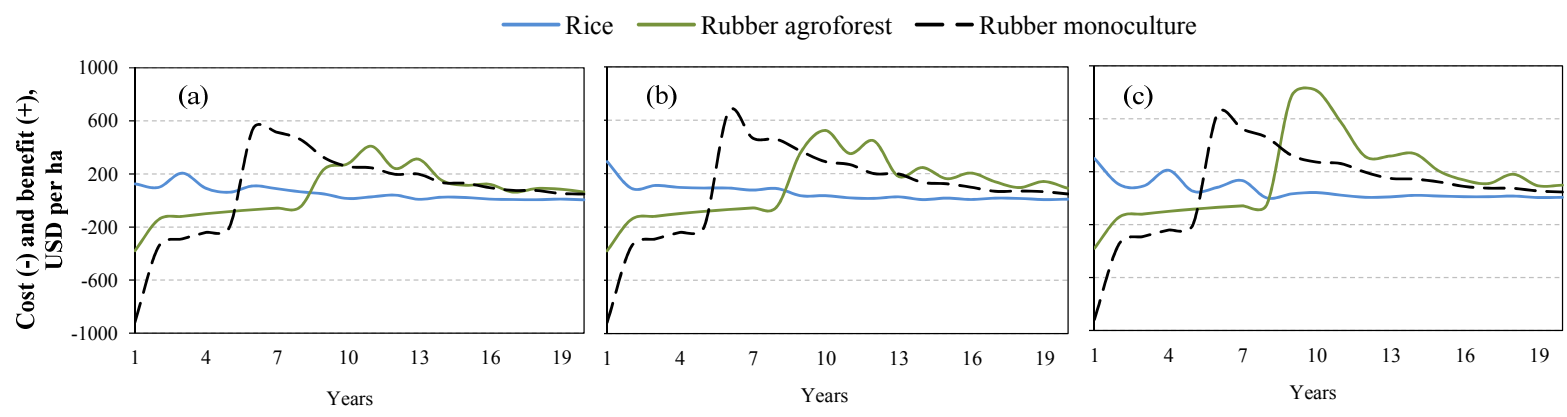

Figure 2. Effect of (a) 10\%, (b) $20 \%$ and (c) $40 \%$ increase on PES price premium on the NPV of the major crops in the study area

\section{CONCLUSIONS}

Our study showed that PES through eco-certification for rubber agroforest landscape performs better in synergizing the key ES such as biodiversity, carbon stock enhancement and crop production compared to BAU scenario. In terms of ES delivery, the different price scenarios for price premium under the ecocertification scheme do not substantially alter the goods and ES delivery. However, between $20 \%$ and $40 \%$ price increase of baseline price, rubber agroforest could compete with rubber monoculture in terms of financial returns. Along with the increase of price premium is the increase of PES adoption.

\section{REFERENCES}

Chen, X., Lupi, F., An, L., Sheely, R., Viña, A., Liu, J., 2012. Agent-based modeling of the effects of social norms on enrollment in payments for ecosystem services. Ecological Modelling 229(0) 16-24.

Evans, T.P., Phanvilay, K., Fox, J., Vogler, J., 2011. An agent-based model of agricultural innovation, landcover change and household inequality: the transition from swidden cultivation to rubber plantations in Laos PDR. Journal of Land Use Science 6(2-3) 151-173.

Grimm, V., Berger, U., DeAngelis, D.L., Polhill, J.G., Giske, J., Railsback, S.F., 2010. The ODD protocol: A review and first update. Ecological Modelling 221(23) 2760-2768.

Le, Q.B., 2005. Multi-agent system for simulation of land-use and land cover change: A theoretical framework and its first implementation for an upland watershed in the Central Coast of Vietnam, Center for Development Research. University of Bonn: Bonn, p. 268.

Le, Q.B., Park, S.J., Vlek, P.L.G., 2010. Land Use Dynamic Simulator (LUDAS): A multi-agent system model for simulating spatio-temporal dynamics of coupled human-landscape system: 2. Scenariobased application for impact assessment of land-use policies. Ecological Informatics 5(3) 203-221.

Le, Q.B., Park, S.J., Vlek, P.L.G., Cremers, A.B., 2008. Land-use dynamic simulator (LUDAS): a multiagent system model for simulating spatio-temporal dynamics of coupled human-landscape system. I. Structure and theoretical specification. Ecological Informatics 2 135-153.

Rahayu, S., 2009. Peran agroforestry karet dalam pelestarian spesies pohon: studi kasus di Desa Lubuk Beringin, Kecamatan Bathin III Ulu, Kabupaten Bungo, Provinsi Jambi: Sekolah Pasca Sarjana. Institut Pertanian Bogor.

Rasnovi, S., 2006. Ecological regenaration of woody species in rubber agroforest system, Sekolah Pascasarjana. Institut Pertanian Bogor: Bogor. 
Sun, Z., Müller, D., 2013. A framework for modeling payments for ecosystem services with agent-based models, Bayesian belief networks and opinion dynamics models. Environmental Modelling \& Software 45(0) 15-28.

Tata, H.L., Panjiwibowo, C., Joshi, L., Benneth, M., Rahayu, S., van Noordwijk, M., 2007. How to define and recognize a rubber agroforest?, World Agroforestry Centre Annual Science Meeting. ICRAF: Nairobi.

Tomich, T.P., van Noordwijk, M., Budidarsono, M., Gillison, A.N., Kusumanto, T., Murdiyarso, D., Stolle, D., Fagi, A.M., 1998. Alternatives to slash-and-burn in Indonesia. Summary Report of Phase II, ASBIndonesia Report No. 8. ASB-Indonesia \& ICRAF: Bogor.

van Noordwijk, M., Tata, H.L., Xu, J., Dewi, S., Minang, P.A., 2012. Segregate or Integrate for Multifunctionality and Sustained Change Through Rubber-Based Agroforestry in Indonesia and China: Agroforestry - The Future of Global Land Use, In: Nair, P.K.R., Garrity, D. (Eds.). Springer Netherlands, pp. 69-104.

Villamor, G.B., 2012. Flexibility of multi-agent system models for rubber agroforest landscapes and social response to emerging reward mechanisms for ecosystem services in Sumatra, Indonesia University of Bonn Press: Bonn, p. 181.

Villamor, G.B., Le, Q.B., Vlek, P.L.G., van Noordwijk, M., 2011. Payments for agro-biodiversity: An analysis of participation in Jambi's conservation agreements for rubber agroforests, (Sumatra) Indonesia, 13th Annual BIOECON Conference on Resource Economics, Biodiversity Conservation and Development: Geneva.

Villamor, G.B., Le, Q.B., Vlek, P.L.G., van Noordwijk, M., under review. Biodiversity, carbon emissions and rural livelihoods in rubber agroforests: An agent-based simulation to preview policy scenarios in lowland Sumatra. Environmental Modelling \& Software.

Villamor, G.B., van Noordwijk, M., 2011. Social role-play games vs individual perceptions of conservation and PES agreements for maintaining rubber agroforests in Jambi (Sumatra), Indonesia. Ecology and Society 16(3) 27.

Wulan, Y.C., Budidarsono, S., Joshi, L., 2008. Economic analysis of improved smallholder rubber agroforestry systems in West Kalimantan, Indonesia - implications for rubber development, Sustainable sloping lands and watershed management conference: Luang Prabang, Lao PDR. 